\title{
Digital competences for smart learning during COVID-19 in higher education students from Spain and Latin America
}

\author{
Ana Pérez-Escoda \\ aperezes@nebrija.es \\ University Antonio de Nebrija, Spain \\ Francisco Javier Lena-Acebo \\ franciscojavier.lena@unican.es \\ University of Cantabria, Spain \\ Rosa García-Ruiz \\ rosa.garcia.unican@gmail.com \\ University of Cantabria, Spain
}

\begin{abstract}
Networked society before pandemic situation had become the context of a technologysupported environment for learning and teaching. Since COVID-19 pandemic occurred learning happened essentially mediated through connected smart devices that demand digital skills and reinforced Smart learning. This study aims to present a descriptive and comparative analysis focusing on digital competences in three different areas: Use, Learning and Critical thinking, justified in a global situation of intensive use of technology. Each area was analyzed considering the five subareas of digital competence: information management, communication, content creation, safety and problem solving. The study was designed under a non-experimental quantitative methodology in which higher education students from Spain, Colombia, Ecuador, and Mexico participated $(\mathrm{N}=926)$. Results show significant differences among countries that could help to improve not only formal education in Higher Education, but the digital skills needed for lifelong learning among citizenship in next future conditioned by recent global situation of pandemic.
\end{abstract}

\section{Keywords}

Digital competences; Smart education; Higher education; Learning; COVID-19; pandemic. 


\section{Introduction}

Envisioned by Marshall McLuhan in the mid-20th century with his global village as a future perspective, the present Society of Knowledge greatly surpasses the expectations of a connected and participative world, compelled towards an unprecedented technological determinism (Ihlebæk, 2018). Together with this phenomenon, the digital transformation of the infrastructures clearly found in two areas: 1) network connections that are becoming more potent (5G, IoT, 4.0 Industry, smart cities, IA etc.) and more influential sources in our society, merging democracy and digitalization through IA development (Pedrero-Esteban \& Pérez-Escoda, 2021) and 2) intelligent devices that are becoming more advanced: smartphones and wearables (Tripathi \& Ahad, 2019) has been propelled by recent COVID-19 crisis. The network becomes the epicenter of the interaction and the functionalist paradigm of linear communication, organized into a hierarchy, and predetermined by a broadcaster and a receiver, has been transformed into an open, interconnected, decentralized, dynamic and flexible scheme (Buckingham, 2020). This change of communication scheme is re-informed and amplified by the effect of pandemic situation all around the world which provided education with a new and radical focus (Marinoni, Land and Jensen, 2020; Crawford et al., 2020) but with new challenges regarding fake news and disinformation, related with digital competences (Pérez-Escoda \& Pedrero-Esteban, 2021). Recent facts have transformed the nature of the ruling paradigms, changing the roles of institutions, moreover the educational ones. As stated by OECD (2020), Covid-19 has accelerated our reliance on digital tools as enablers to continue learning while schools and universities has remained closed.

\section{a. Born digital, nurture connected and obliged by the pandemic}

As a product of the change in context, we find a juncture which deserves a more in-depth reflection: the exposure of the generations born after the year 2000 to technology in an unprecedent situation where stay connected seems to be the only option. This population have been sociologically conceptualized under different names: digital natives, digital generation, generation Z (Tapscott, 2008; Gardner \& Davis, 2014) as a cohort that has grown immersed in tactile and connected technologies, collaborative and networked games, YouTube tutorials and social networks (Feijoo-Fernández, Sádaba, \& Bugueño, 2020). Born in a technological context, the new generations have developed a sort of dependence and naturalization towards the digital (Gardner \& Davis 2014).

This framework for new generations born digital and nurture connected has been intensified since the pandemic situation collapsed the world in March 2020 promoting distrust and information disorders (Pérez-Escoda, Pedrero-Esteban, Rubio \& Jiménez, 2021). Despite the enormous consequences in economic, social, work and health areas it is worth noting the greater increase of Internet users all around the world. According to the last report from We are Social 2021, 1.3 million people joined any social network during the lockdown for Covid-19 which means a total of 4.3 million users for social networks globally speaking, an annual increase of $13 \%$. The Internet penetrations corresponding to the countries analyzed is: $92 \%$ in Spain, $81 \%$ in Ecuador, $65 \%$ in Mexico and $63 \%$ in Colombia (Newman et al., 2021). In this line the Digital News Report from the Reuters Institute (Newman et al., 2021) highlight how the pandemic situation has also intensified the Internet use not only in entertainment areas (games, videos, music, sports, etc.) but in information consumption which introduces other specific problems such as fake news and misinformation requiring high levels of development in digital competences among citizens (PérezEscoda, García-Ruiz \& Lena, 2021). 


\section{b. Digital competence and smart learning}

The social and economic changes due the Covid-19 pandemic situation ratify the need for digital competencies that imply substantial and structural modification in their literacy (García-Ruiz \& Pérez-Escoda, 2019). There are different approaches that describe digital competencies related with all the activities that an online environment offers us from different areas of action (GarcíaRuiz \& Pérez-Escoda, 2021; Pettersson, 2018, Cabero, Romero, \& Palacios, 2020; Redecker \& Punie, 2017). Table 1 shows the areas used in this study and their definition.

\begin{tabular}{|l|l|}
\hline Areas & \multicolumn{1}{|c|}{ Definition } \\
\hline Information and data literacy & $\begin{array}{l}\text { Use technologies to access, find, organize, edit and } \\
\text { manage digital information }\end{array}$ \\
\hline collaboration & $\begin{array}{l}\text { Identified as the ability to interact, communicate and } \\
\text { collaborate through digital technologies and be able to } \\
\text { participate in society and in participatory citizenship } \\
\text { through public or private digital services }\end{array}$ \\
\hline Security & $\begin{array}{l}\text { Defined as the ability to create and edit digital content, } \\
\text { to improve and integrate information and content into an } \\
\text { existing body of knowledge while understanding how } \\
\text { copyright and licenses are to be applied }\end{array}$ \\
\hline Problem solving & $\begin{array}{l}\text { Related to the concepts of protection of devices personal } \\
\text { data and health from the perspectives of use, learning } \\
\text { and critical thinking }\end{array}$ \\
\hline
\end{tabular}

Table 1. Areas of competencies and sub-competencies from digital competence. Source: Created from Redecker, \& Punie (2017) and Carretero, Vourikari \& Punie (2017).

Our study focuses not only on these competences but in levels of proficiency, applied in terms of use, learning and critical thinking outcomes as described below. According to literature from digital inequalities, the basic idea stems from a doble perspective: inequality from access and inequality from use (van Deursen, 2020). The study presented aims to analyse the inequality from use, analysing two different contexts: Spain and Latin American countries (Colombia, Mexico and Ecuador) in order to study possible inequalities in university students facing the COVID-19 situation. The differences between both frameworks remain in terms of well-beings shown in Figure 1 , however all countries in sample were the most affected by COVID- 19 . 


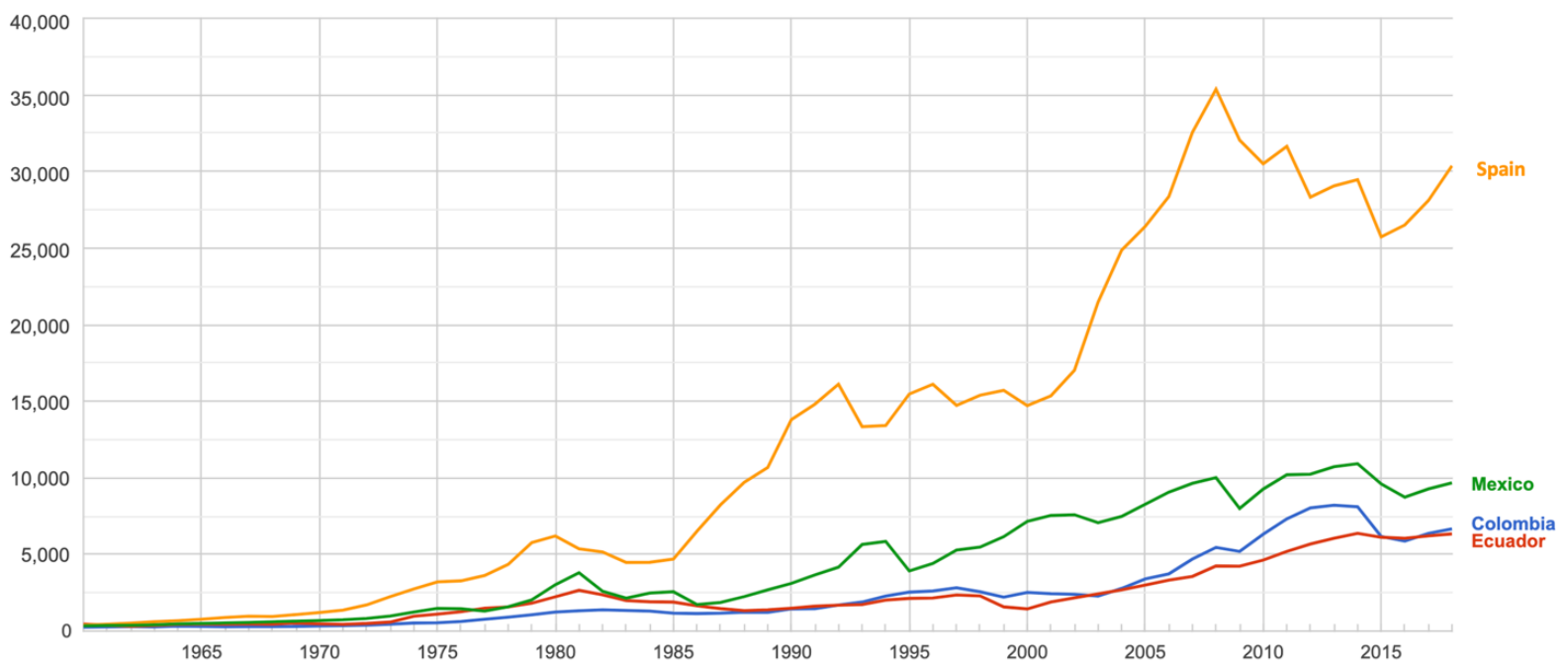

Figure. 1. GDP in countries studies. Source: World Bank, September 2020. Source: Google Public Data

Although a unanimous conceptualization of smart learning does not exist, there seems to be consensus in the fact that it is a type of learning where smart devices intervene and where digital competences remain essential. Smart learning or smart education, as expressed by $L i$, Tsang and Wong (2020) is more an educational paradigm of technology-enhanced learning emerging since the 2010s. Hwang and Choi described it as a "new 21st century educational paradigm that fosters and develops all students to become global leaders by renovating the existing education system, such as educational contents, methods, evaluations, and environments" (2016, p. 2). Learning during lockdown has been developed basically through smart devices in informal contexts, this is out of schools and universities (Crawford et al., 2020; Di Pietro et al., 2020; Dneprovskaya, Komleva \& Urintsov, 2020). Covid-19 situation has globally exposed educational systems to equal necessities in terms of students subjected to a global lockdown only with technology mediating all kind of relations, education included.

According to this situation explained, the research proposed acquires special importance in the context of Latin countries: Spain and Latin America, where a smart learning definition and model is sought starting from evidence of the development of soft skills of the students in informal contexts that shelter the development of smart education (Chen, Cheng, \& Chew, 2016; Bakken, Uskov, \& Penumatsa, 2019), because, as pointed out by Hwang "new learning modes will raise new pedagogic issues" (2014, p. 11), even more since COVID-19 pandemic impose a global lockdown.

\section{Research Methods}

The methodological research design was quantitative and descriptive-comparative, as the intention is to describe the basic components of a specific phenomenon by extracting them from a given content through the process that is characterized by the rigor of their measurement. To collect the data, an instrument was created ad hoc, whose study variables were defined starting from the study of existing European proposals from Redecker \& Punie (2017) and Carretero, Vuorikova and Punie (2017).

The result of this previous in depth study resulted in the design of an online questionnaire with a matrix of independent variables for the collection of sociodemographic data, and a matrix of 100 items groups in study constructs, with two dimensions of analysis: (a) a first one level with three areas of study that collected data on formal and informal environments; use, learning and 
participation and (b) a second level, within each area where five digital competence subareas were studied as shown in Table 1 . Using a Likert scale, the levels were determined as Never, Rarely, Often, and Always. This first questionnaire was submitted to expert judges who evaluated the pertinence and the clarity of all the items. As a result of this evaluation, 25 items were discarded, as they did not comply with the criteria established for pertinence and clarity. Figure 2 shows all areas and subareas addressed in the study.

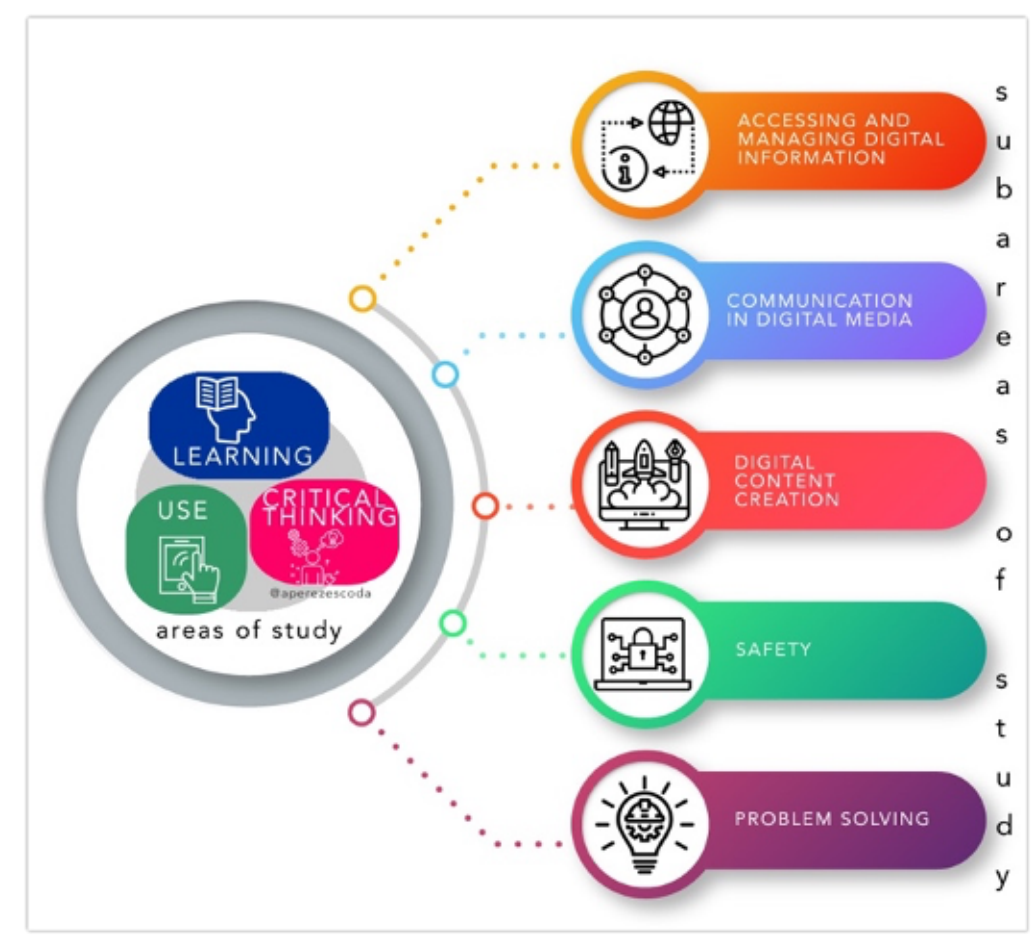

Figure. 2. Areas and subareas of study. Source: Own elaboration.

The statistical reliability of the instrument was analysed with Cronbach's alpha values for each area of study and country to guarantee the validity of the scale. In both cases, the internal consistency calculated resulted in values greater than 0.7 , so the internal consistency of the instrument can be acceptable, as well its validity for the present study. An index of 0.79 was found for the area of Use, 0.8 for the area of Learning, and the 0.74 for the area of Critical thinking in the case of Spain, and 0.75 in the areas of "Use", 0.80 for the area of "Learning", and 0.82 in the area of "Critical thinking" in the case of Latin America. Data coding was established as can be seen in Table 0 (https://doi.org/10.6084/m9.figshare.11881449).

A convenience sampling was utilized to guarantee the high number of responses, with the sample composed by university students aged 17 to $30(\mathrm{~N}=969)$ belonging to Spain $(\mathrm{N}=253)$ and Latin America $(\mathrm{N}=716)$. These students were enrolled at eight different universities in four different countries: Colombia, Ecuador, Mexico and Spain. The description of the sample according to country, gender and age is shown in Table 2. 


\begin{tabular}{|c|c|c|c|c|c|c|c|}
\hline & & $\begin{array}{l}\text { Colombia } \\
N=228 \\
(23.5 \%)\end{array}$ & $\begin{array}{c}\text { Ecuador } \\
N=258 \\
(26,6 \%)\end{array}$ & $\begin{array}{c}\text { Mexico } \\
N=230 \\
(23.7 \%)\end{array}$ & $\begin{array}{c}\text { Latin } \\
\text { America } \\
\mathrm{N}=716 \\
(73.9 \%)\end{array}$ & $\begin{array}{c}\text { Spain } \\
\mathrm{N}=253 \\
(26.1)\end{array}$ & $\begin{array}{c}\text { Total } \\
N=969\end{array}$ \\
\hline Gende & Male & $\begin{array}{c}184 \\
(80.7 \\
\%)\end{array}$ & $\begin{array}{c}193 \\
(74.8 \\
\%)\end{array}$ & $\begin{array}{c}146 \\
(63.5 \%)\end{array}$ & $\begin{array}{c}523 \\
(72.9 \%)\end{array}$ & $\begin{array}{c}204 \\
(80.6 \\
\%)\end{array}$ & $\begin{array}{c}727 \\
(75.0 \\
\%)\end{array}$ \\
\hline r & $\begin{array}{c}\text { Femal } \\
\mathrm{e}\end{array}$ & $\begin{array}{c}44 \\
(19.3 \\
\%)\end{array}$ & $\begin{array}{c}65 \\
(25.2 \\
\%)\end{array}$ & $\begin{array}{c}84 \\
(36.5 \%)\end{array}$ & $\begin{array}{c}193 \\
(27.1 \%)\end{array}$ & $\begin{array}{c}49 \\
(19.4 \\
\%)\end{array}$ & $\begin{array}{c}242 \\
(25.0 \\
\%)\end{array}$ \\
\hline & $17-24$ & $\begin{array}{c}197 \\
(86.4 \\
\%)\end{array}$ & $\begin{array}{c}242 \\
(93.8 \\
\%)\end{array}$ & $\begin{array}{c}203 \\
(88.3 \%)\end{array}$ & $\begin{array}{c}642 \\
(89.5 \%)\end{array}$ & $\begin{array}{c}148 \\
(58.5 \\
\%)\end{array}$ & $\begin{array}{c}790 \\
(81.5 \\
\%)\end{array}$ \\
\hline Age & $25-30$ & $\begin{array}{c}26 \\
(11.4 \\
\%)\end{array}$ & $\begin{array}{c}13 \\
(5.0 \% \\
\quad)\end{array}$ & $\begin{array}{c}24 \\
(10.4 \%)\end{array}$ & $\begin{array}{c}63 \\
(8.8 \%)\end{array}$ & $\begin{array}{c}57 \\
(22.5 \\
\%)\end{array}$ & $\begin{array}{c}120 \\
(12.4 \\
\%)\end{array}$ \\
\hline & +30 & $\begin{array}{c}5 \\
(2.2 \% \\
)\end{array}$ & $\begin{array}{c}3 \\
(1.2 \% \\
\quad)\end{array}$ & $\begin{array}{c}3 \\
(1.2 \%)\end{array}$ & $\begin{array}{c}11 \\
(1.5 \%)\end{array}$ & $\begin{array}{c}48 \\
(29.0 \\
\%)\end{array}$ & $\begin{array}{c}59 \\
(6.1 \% \\
)\end{array}$ \\
\hline
\end{tabular}

Table 2. Description of the sample according to age and gender. Source: Own elaboration.

It should be highlighted that despite the samples in both contexts not being the same in number, the comparison between them, it could make sense as it is a comparison of the difference in means between the two independent groups of sufficiently large sizes.

\section{Results and data analysis}

Results were obtained with the software program SPSS version 25, as for the basic statistical descriptions (means and standard deviations). The Mann-Whitney $U$ test was utilized for the study of significant differences between the samples of two groups, as it is considered to be one of the most useful for working with non-parametric data (Nachar, 2008). To estimate the results, the effect size was evaluated according to the $\eta^{2}$ value, with the small effect considered for values that exceed $\eta^{2}=0.01$ and a moderate effect for those that exceeded $\eta^{2}=0.39$ (Cohen 1988). Both statistical tests were studied on the three constructs: Use, Learning and Critical thinking analyzed in a total of 75 items ( 25 for each of the three constructs). Results are presented according to all five subareas determined in the three areas stablished: Use, Learning and Critical thinking as shown in Figure 2 and only the item where significant differences and observable effect size were found, are shown.

\section{a. Accessing and Managing Digital Information}

Statistically significant differences were found, as shown in Table 3, in the "Use habits for searching videos in YouTube" between the Spanish sample and the Latin American one, with its frequency being greater in the second population $\left(U=79769.00, p<0.000, \eta^{2}=0.017\right)$. The Latin American sample utilized YouTube more frequently for searching for videos. This was also the case for saving information found on the Internet, with more frequent results in Latin America $(U=77375.00$, $\left.p<0.000, \eta^{2}=0.014\right)$. 


\begin{tabular}{|c|c|c|c|c|c|c|c|c|}
\hline $\begin{array}{l}\text { Areas of } \\
\text { study }\end{array}$ & $\begin{array}{l}\text { Items presenting } \\
\text { significant differences }\end{array}$ & & Mean & SD & $\begin{array}{l}\text { Mean } \\
\text { Rank }\end{array}$ & $\begin{array}{c}\text { Mann- } \\
\text { Whitney U }\end{array}$ & $\begin{array}{l}\text { Asym. } \\
\text { Sig. } \\
(2-\end{array}$ & $\eta^{2}$ \\
\hline \multirow{6}{*}{$\begin{array}{l}\text { EVERYDAY } \\
\text { USE }\end{array}$} & \multirow{3}{*}{$\begin{array}{l}\text { Item 1(4Ua): I search for } \\
\text { videos on YouTube }\end{array}$} & SP* & 3.39 & 0.611 & 430.43 & & & \\
\hline & & $\mathrm{AM} * *$ & 3.56 & 0.585 & 504.28 & & & \\
\hline & & Total & 3.51 & 0.596 & & 76769.00 & 0.000 & 0.017 \\
\hline & \multirow{3}{*}{$\begin{array}{l}\text { Item } 2 \text { ( } 5 \mathrm{Ua}) \text { : I store the } \\
\text { information I find on the } \\
\text { Internet so I can use when } \\
\text { I need it }\end{array}$} & SP* & 2.84 & 0.750 & 432.83 & & & \\
\hline & & $\mathrm{AM}^{* *}$ & 3.05 & 0.793 & 503.43 & & & \\
\hline & & Total & 3.00 & 0.787 & & 77375.00 & 0.000 & 0.014 \\
\hline \multirow{6}{*}{ LEARNING } & \multirow{3}{*}{$\begin{array}{l}\text { Item } 3 \text { (4La): I edit } \\
\text { information on Wikipedia } \\
\text { about subjects I know } \\
\text { about }\end{array}$} & SP* & 1.34 & 0.670 & 390.65 & & & \\
\hline & & $\mathrm{AM} * *$ & 1.77 & 0.903 & 518.34 & & & \\
\hline & & Total & 1.66 & 0.868 & & 66703.00 & 0.000 & 0.050 \\
\hline & \multirow{3}{*}{$\begin{array}{l}\text { Item } 4 \text { (5La): I search for } \\
\text { information in videos to } \\
\text { understand some subjects } \\
\text { better }\end{array}$} & SP* & 2.70 & 0.663 & 400.75 & & & \\
\hline & & $\mathrm{AM}^{* *}$ & 3.02 & 0.728 & 514.77 & & & \\
\hline & & Total & 2.94 & 0.725 & & 69257.50 & 0.000 & 0.039 \\
\hline \multirow{3}{*}{$\begin{array}{l}\text { CRITICAL } \\
\text { THINKING }\end{array}$} & \multirow{3}{*}{$\begin{array}{l}\text { Item } 5 \text { ( } 2 \mathrm{Ca}) \text { : The } \\
\text { Internet allows me to stay } \\
\text { current on the news or } \\
\text { events which other media } \\
\text { would not allow me to be } \\
\text { familiar with }\end{array}$} & SP* & 3.34 & 0.595 & 544.06 & & & \\
\hline & & $\mathrm{AM}^{* *}$ & 3.12 & 0.687 & 464.13 & & & \\
\hline & & Total & 3.18 & 0.671 & & 75631.50 & 0.000 & 0.019 \\
\hline
\end{tabular}

* (SP) Spanish sample $\mathrm{N}=253$ ** (AM) Latin American sample (Colombia, Ecuador and Mexico) N=716 Note. ${ }^{*} \mathrm{p}<.05$.

Table 3. Accessing and Managing Digital Information. Source: Own elaboration

If the response distribution figures are observed for each of the items, Figure 3, it is confirmed how the differences between both samples are evident.

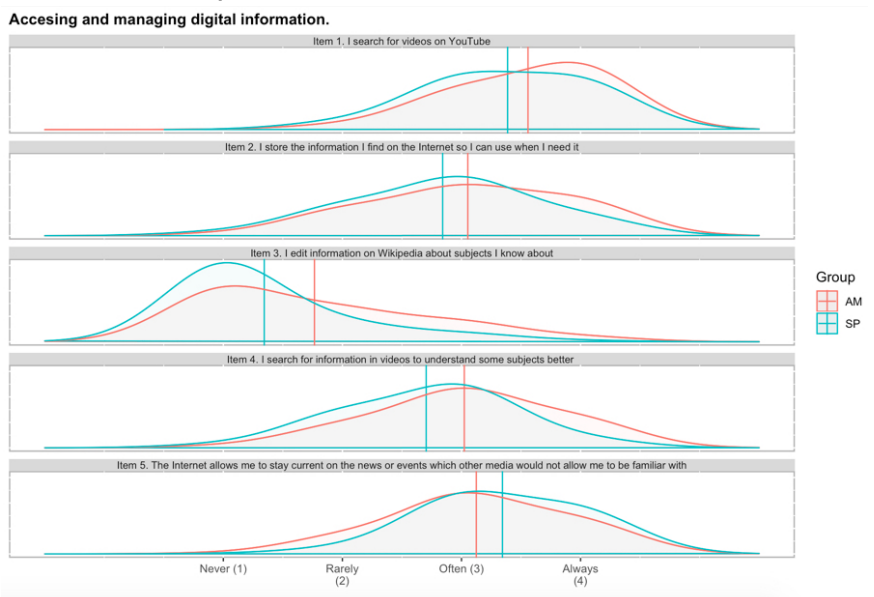

Figure 3. Distribution of the items with statistically significant differences and with a noticeable effect size in the area of access and management of digital information. Source: Own elaboration 


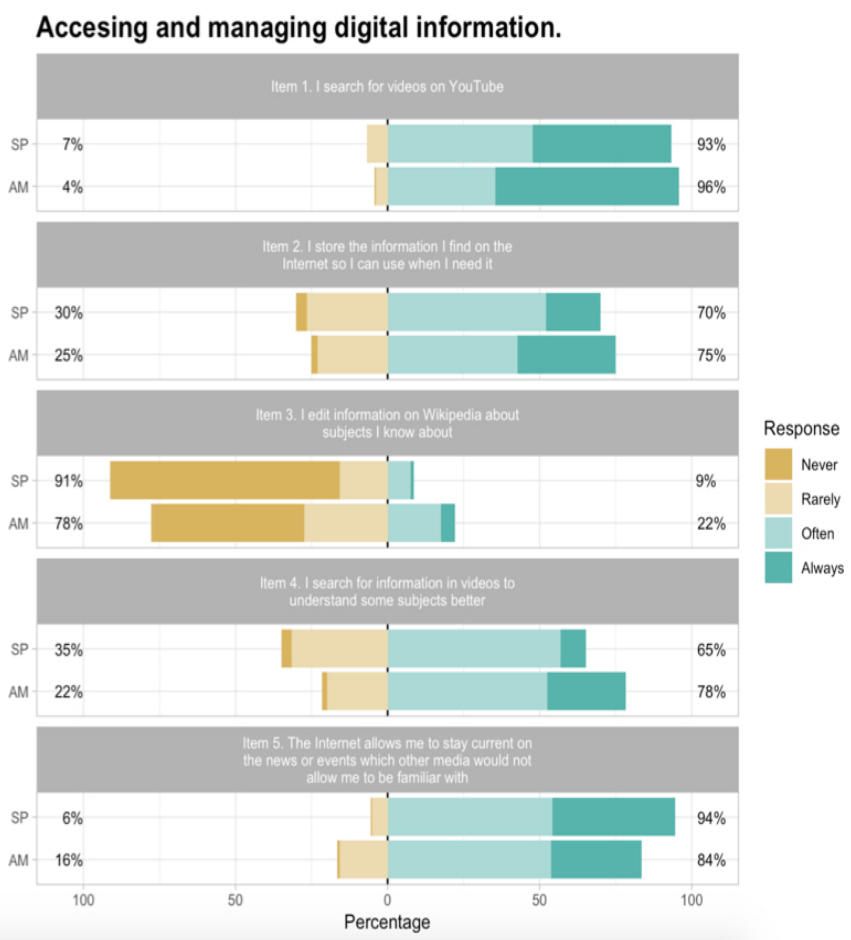

Figure 4. Graphical representation of the percentages of the response according to items with statistically significant differences and noticeable effect size. Source: Own elaboration

The percentages of response in both contexts in the case of the items $1,2,4$ and 5 , indicate that most of the sample usually or always performs the activities planned, with more frequent significant differences in the Latin American context for the area "Use" item "Saving information for using it when needed" (M1=2.84 SD=0.75 M2=3.05 SD=0.79 U=77375.0 $\left.P<0.000 \eta^{2}=0.014\right)$ and also for the area of "Critical thinking" (M1=2.70 SD=0.66 M2=3.02 SD=0.73 U=69257.5 P $<0.000$ $\left.\eta^{2}=0.039\right)$.

\section{b. Communication in Digital media}

As for the second subarea of study statistically significant differences $(p<0.05)$ and noticeable effect size were found in eight different items as shown in Table 4.

\begin{tabular}{|c|c|c|c|c|c|c|c|}
\hline $\begin{array}{l}\text { Areas of } \\
\text { study }\end{array}$ & $\begin{array}{l}\text { Items presenting significant } \\
\text { differences }\end{array}$ & & Mean & SD & $\begin{array}{l}\text { Mean } \\
\text { Rank }\end{array}$ & $\begin{array}{l}\text { Sig. }(2- \\
\text { Tailed })\end{array}$ & $\eta^{2}$ \\
\hline \multirow{6}{*}{ USE } & \multirow{3}{*}{$\begin{array}{l}\text { Item } 1(6 \mathrm{Uc}) \text { : I quickly answer any } \\
\text { message I receive }\end{array}$} & SP* & 2.94 & 0.670 & 528.48 & & \\
\hline & & $\mathrm{AM}^{* *}$ & 2.78 & 0.737 & 469.64 & & \\
\hline & & Total & 2.82 & 0.723 & & .002 & .010 \\
\hline & \multirow{3}{*}{$\begin{array}{l}\text { Item } 2(10 \mathrm{Uc}): \text { I prefer to } \\
\text { communicate with others through the } \\
\text { internet than in person }\end{array}$} & SP* & 1.68 & 0.705 & 379.75 & & \\
\hline & & AM** & 2.11 & 0.817 & 522.19 & & \\
\hline & & Total & 1.99 & 0.811 & & .000 & .058 \\
\hline & \multirow{3}{*}{$\begin{array}{l}\text { Item } 3(6 \mathrm{Lc}): \text { I communicate through } \\
\text { the Internet to doing collaborative } \\
\text { work with my classmates }\end{array}$} & SP* & 2.92 & 0.829 & 399.35 & & \\
\hline & & $\mathrm{AM}^{* *}$ & 3.28 & 0.668 & 515.26 & & \\
\hline & & Total & 3.19 & 0.731 & & .000 & .039 \\
\hline
\end{tabular}




\begin{tabular}{|c|c|c|c|c|c|c|c|}
\hline \multirow{9}{*}{ LEARNING } & \multirow{3}{*}{$\begin{array}{l}\text { Item } 4(7 \mathrm{Lc}) \text { : Communicating through } \\
\text { the Networks helps me learn }\end{array}$} & SP* & 2.71 & 0.750 & 436.72 & & \\
\hline & & $\mathrm{AM}^{* *}$ & 2.91 & 0.734 & 502.06 & & \\
\hline & & Total & 2.85 & 0.743 & & .000 & .013 \\
\hline & \multirow{3}{*}{$\begin{array}{l}\text { Item } 5(9 \mathrm{Lc}) \text { : We help each other with } \\
\text { the works and exams with WhatsApp } \\
\text { or another chat application }\end{array}$} & SP* & 3.16 & 0.868 & 579.33 & & \\
\hline & & $\mathrm{AM} * *$ & 2.72 & 0.951 & 451.61 & & \\
\hline & & Total & 2.83 & 0.950 & & .000 & .045 \\
\hline & \multirow{3}{*}{$\begin{array}{l}\text { Item } 6(10 \mathrm{Lc}) \text { : I use platforms such } \\
\text { as Moodle or blogs to communicate } \\
\text { with my professors }\end{array}$} & SP* & 2.81 & 0.913 & 620.96 & & \\
\hline & & $\mathrm{AM} * *$ & 2.14 & 0.944 & 436.96 & & \\
\hline & & Total & 2.31 & 0.982 & & .000 & .090 \\
\hline \multirow{6}{*}{$\begin{array}{l}\text { CRITICAL } \\
\text { THINKING }\end{array}$} & \multirow{3}{*}{$\begin{array}{l}\text { Item } 7 \text { (9Cc): I have reported a } \\
\text { situation of cyberbullying }\end{array}$} & SP* & 1.33 & 0.723 & 390.92 & & \\
\hline & & $\mathrm{AM}^{* *}$ & 1.82 & 1.040 & 518.24 & & \\
\hline & & Total & 1.69 & 0.991 & & .000 & .052 \\
\hline & \multirow{3}{*}{$\begin{array}{l}\text { Item } 8(10 \mathrm{Cc}): \text { I disseminate every I } \\
\text { receive through the networks }\end{array}$} & SP* & 1.51 & 0.561 & 431.59 & & \\
\hline & & AM** & 1.76 & 0.803 & 503.87 & & \\
\hline & & Total & 1.70 & 0.755 & & .000 & .015 \\
\hline
\end{tabular}

* (SP) Spanish sample $\mathrm{N}=253 * *$ (AM) Latin American sample (Colombia, Ecuador and Mexico) $\mathrm{N}=716$ Note. $\mathrm{p}<.05$.

Table 4. Communication in Digital Media. Source: Own elaboration

Data let us observe that the Spanish sample is more proactive to quickly answering every type of digital message, as shown by the comparative analysis $\left(U=79573.00, p<0.002, \eta^{2}=0.010\right)$. As for a mean of 2.78 in Latin American sample, a value of 2.94 was found in the Spanish sample

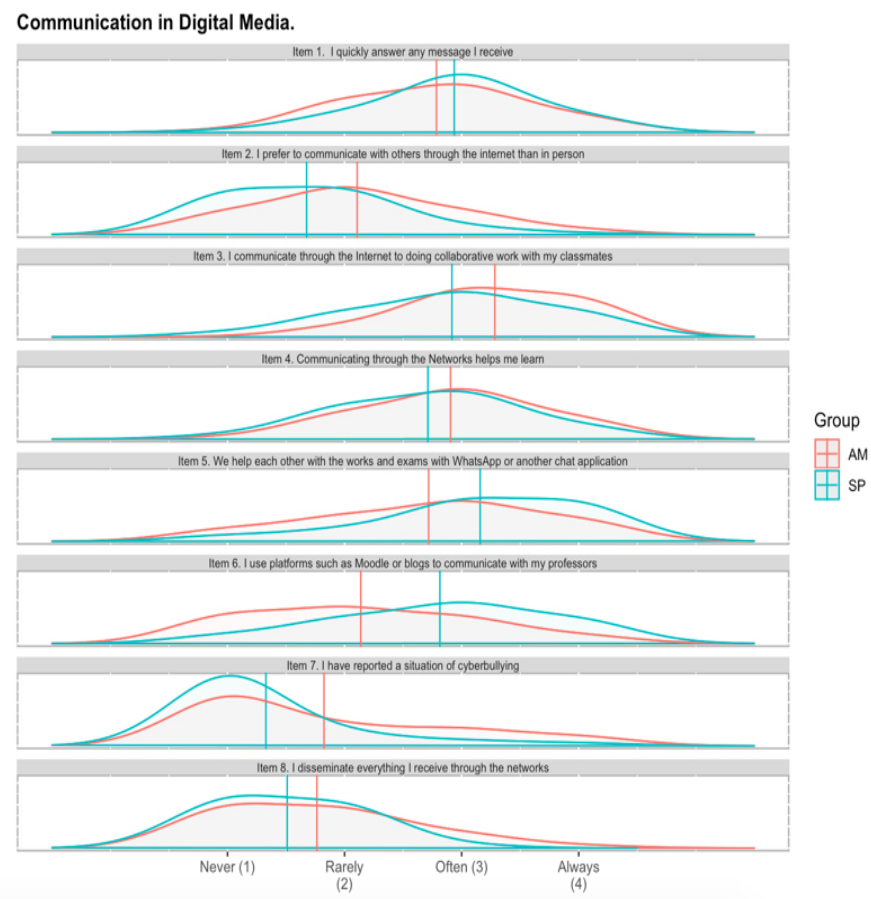

Figure 5. Distribution figures of the items with statistically significant differences and noticeable effect size in the area of Communication in digital media.Source: Own elaboration 
This trend is re-enforced if we take into account the results of the item "We help each other with the work and exams through WhatsApp or other chats", where an important difference was found between both samples $\left(\mathrm{U}=66709.00, \mathrm{p}<0.000, \eta^{2}=0.045\right)$ as more clearly shown in Figure 5 and Figure 6. For a mean of 2.72 for the Latin American countries, a value of 3.16 was found for Spain. The communication with the teachers was more intense for the Spanish sample, 2.81, as compared to $2.14\left(\mathrm{U}=66709.00, \mathrm{p}<0.000, \eta^{2}=0.090\right)$.

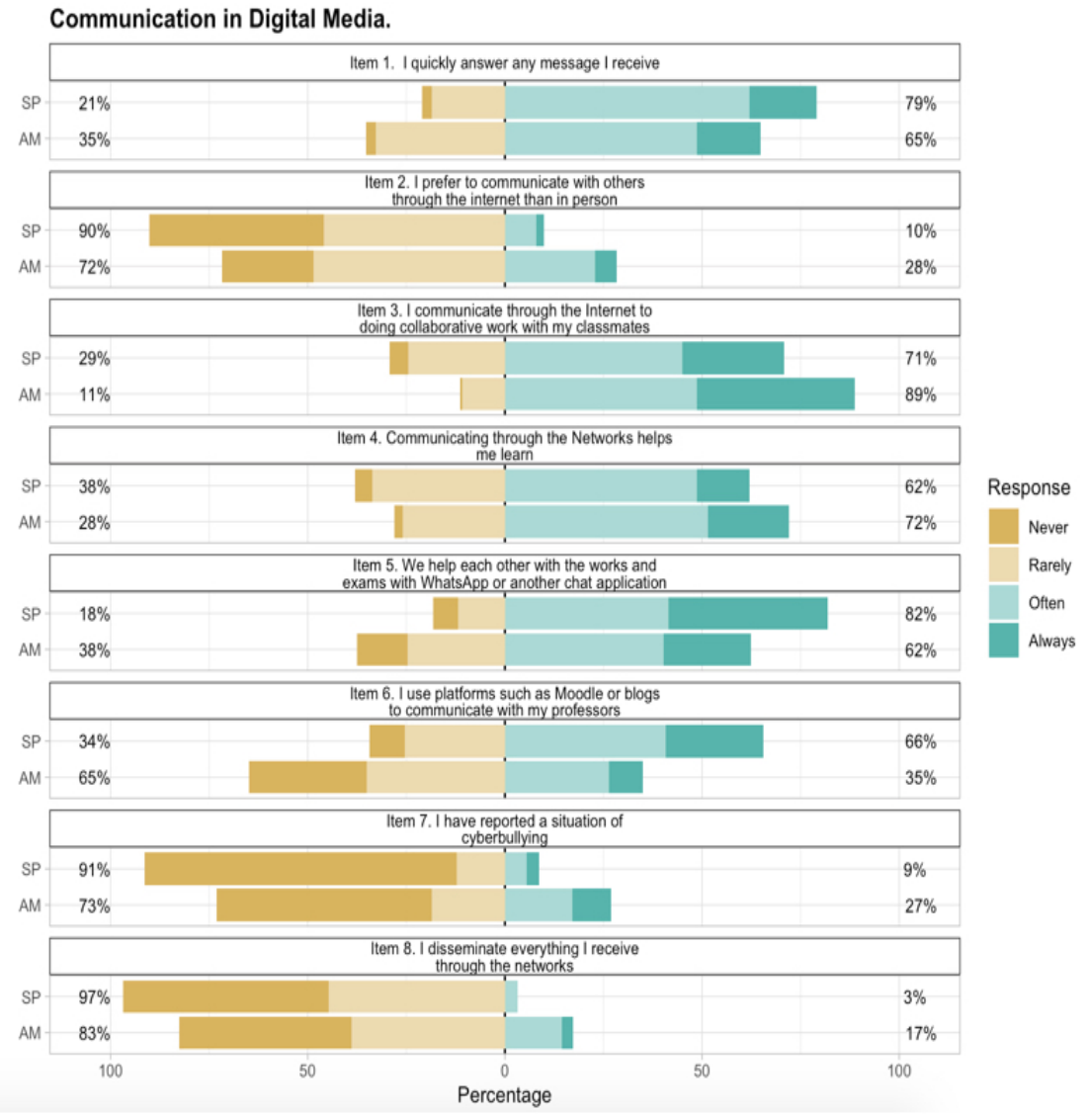

Figure 6. Graphical representation of the response percentages according to items with statistically significant differences and noticeable effect size in the area of Communication in digital media. Source: Own elaboration

\section{c. Digital content creation}

The results when speaking about a participative culture that is characterized by the emergence of a citizen who naturally creates and shares content through connected devices, show many significant differences in the items studies, as shown in Table 5.

\begin{tabular}{|c|c|c|c|c|c|c|c|}
\hline $\begin{array}{l}\text { Areas of } \\
\text { study }\end{array}$ & Items presenting significant differences & & Mean & SD & $\begin{array}{l}\text { Mean } \\
\text { Rank }\end{array}$ & $\begin{array}{l}\text { Sig. }(2- \\
\text { Tailed })\end{array}$ & $\eta^{2}$ \\
\hline & \multirow{3}{*}{$\begin{array}{l}\text { Item } 1(12 \mathrm{Ud}) \text { : I configure my profile in } \\
\text { the social networks so that it is private }\end{array}$} & SP* & 3.49 & 0.824 & 529.65 & & \\
\hline & & $\mathrm{AM} * *$ & 3.31 & 0.880 & 469.22 & & \\
\hline & & Total & 3.36 & 0.869 & & .001 & .011 \\
\hline \multirow[b]{2}{*}{ USE } & \multirow{2}{*}{$\begin{array}{l}\text { Item } 2 \text { ( } 14 U d): \text { I accept invitations } \\
\text { from unknown people }\end{array}$} & SP* & 1.36 & 0.586 & 437.47 & & \\
\hline & & $\mathrm{AM} * *$ & 1.56 & 0.745 & 501.79 & & \\
\hline
\end{tabular}




\begin{tabular}{|c|c|c|c|c|c|c|c|}
\hline & & Total & 1.51 & 0.712 & & .000 & .014 \\
\hline & Item 3 ( $15 U d)$ : I cover my webcam & SP* & 3.04 & 1.289 & 580.79 & & \\
\hline & & $\mathrm{AM} * *$ & 2.40 & 1.280 & 451.15 & & \\
\hline & & Total & 2.57 & 1.313 & & .000 & .046 \\
\hline & Item 4(12Ld): The work I share on the & SP* & 1.92 & 0.849 & 407.21 & & \\
\hline & $\begin{array}{l}\text { Internet with my classmates can be } \\
\text { copied by others }\end{array}$ & $\mathrm{AM} * *$ & 2.27 & 0.880 & 512.49 & & \\
\hline & & Total & 2.18 & 0.885 & & .000 & .030 \\
\hline & Item 5 (13Ld): I share my passwords of & SP* & 1.53 & 0.833 & 434.31 & & \\
\hline & work for the courses with my & $\mathrm{AM} * *$ & 1.75 & 0,895 & 502.91 & & \\
\hline & & Total & 1.70 & 0.884 & & .000 & .014 \\
\hline & Item $6(13 \mathrm{Cd}):$ I can delete the content & SP* & 1.81 & 0.858 & 398.95 & & \\
\hline & $\begin{array}{l}\text { 1 shared on the Internet without leaving } \\
\text { a trace }\end{array}$ & $\mathrm{AM} * *$ & 2.21 & 0.939 & 515.41 & & \\
\hline & & Total & 2.10 & 0.935 & & .000 & .037 \\
\hline & Item 7 (14Cd): Participating in & SP* & 2.88 & 0.920 & 548.33 & & \\
\hline $\begin{array}{l}\text { CRITICAL } \\
\text { THINKING }\end{array}$ & $\begin{array}{l}\text { networks makes it easy for others to } \\
\text { use my data without permission }\end{array}$ & $\mathrm{AM} * *$ & 2.57 & 0.989 & 462.62 & & \\
\hline & & Total & 2.65 & 0.981 & & .000 & .020 \\
\hline & Item $8(15 \mathrm{Cd}):$ I configure all my & SP* & 3.49 & 0.795 & 536.93 & & \\
\hline & profiles so that they are private & $\mathrm{AM} * *$ & 3.25 & 0.910 & 466.65 & & \\
\hline & & Total & 3.31 & 0.887 & & .000 & .015 \\
\hline
\end{tabular}

* (SP) Spanish sample $\mathrm{N}=253 * *$ (AM) Latin American sample (Colombia, Ecuador and Mexico) $\mathrm{N}=716$ Note. $\mathrm{p}<.05$

Table 5. Digital Content Creation. Source: Own elaboration

In the area of "Use", statistically significant differences are found in "Configuration of social networks profiles" with the frequency being higher in the case of the Spanish sample $\left(\mathrm{U}=79277.00, \mathrm{p}<0.000, \eta^{2}=0.011\right)$, which denotes a greater suspicion about their privacy. This trend is confirmed in the case of covering the webcam on their laptops, a gesture that is also more disseminated among the sample in Spain $\left(U=66340, p<0.000, \eta^{2}=0.046\right)$. The attitude shown in the area of "Use" is also re-enforced in the items that show significant differences in the case of the area of "Learning", where the item "Sharing works online" $\left(U=70893.00, p<0.000, \eta^{2}=0.030\right)$ and "Sharing passwords with colleagues" $\left(U=77748.00, p<0.000, \eta^{2}=0.014\right)$ is more commonly done among Latin American sample than in the case of Spanish university students. 


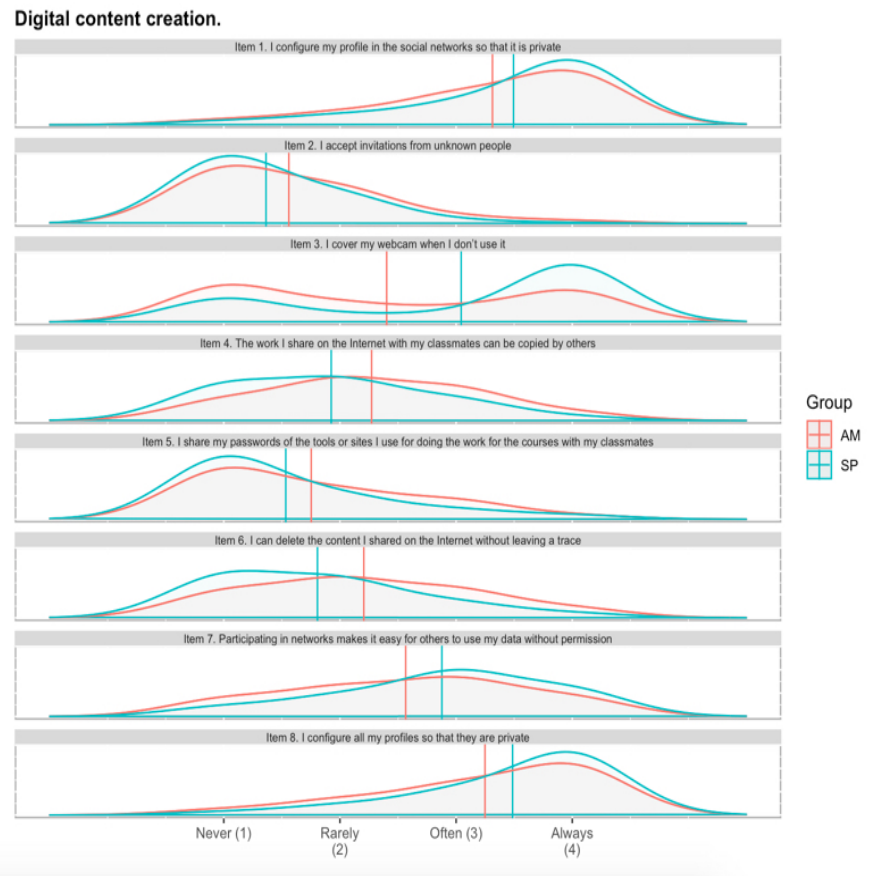

Figure 7. Distribution figures of the items with statistically significant differences and noticeable effect size in the area of content creation. Source: Own elaboration

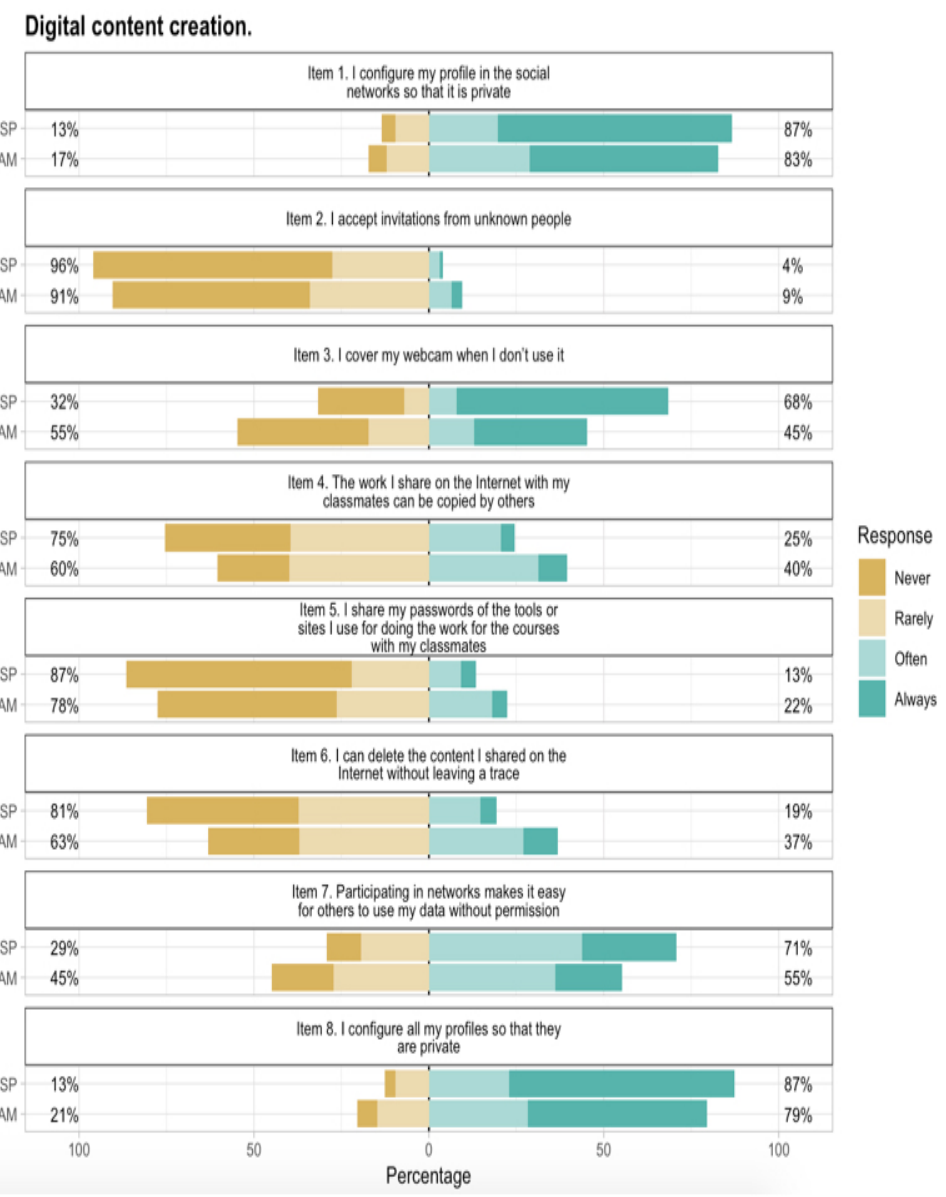

Figure 8. Distribution figures of the items with statistically significant differences and noticeable effect size in the area of content creation. Source: Own elaboration 
Figures 7 and 8 visually show the significant differences, but also the trends in both samples whose behavior in the case of "Critical thinking" reveals important differences. In the case of "Deleting content on the Internet without leaving a trace", the Latin American sample shows a very different behavior with a percentage of $19 \%$ of individuals who confirm doing it often or always as compared to $37 \%$ of the Spanish sample $(\mathrm{M} 1=1.81 \mathrm{SD}=0.85 \mathrm{M} 2=2.21 \mathrm{SD}=0.93 \mathrm{U}=68803.0 \mathrm{P}<0.000$ $\left.\eta^{2}=0.037\right)$. Likewise, the Spanish sample shows to have a more important perception in the item "Participating in networks facilitates that other use my data without permission" with a percentage of $77 \%$, as compared to $55 \%$ in the case of the Latin American sample (M1=2.88 SD=0.92 $\left.\mathrm{M} 2=2.57 \mathrm{SD}=0.98 \mathrm{U}=74552.0 \mathrm{P}<0.000 \eta^{2}=0.020\right)$.

\section{d. Safety}

One of the competences that generates the most debate considering bad practices, abuses and negative habits is related with "Safety" subarea. This area revealed significant differences in both geographic areas in nine items as shown in Table 6.

\begin{tabular}{|c|c|c|c|c|c|c|c|}
\hline $\begin{array}{l}\text { Areas of } \\
\text { study }\end{array}$ & $\begin{array}{l}\text { Items presenting significant } \\
\text { differences }\end{array}$ & & Mean & SD & $\begin{array}{l}\text { Mean } \\
\text { Rank }\end{array}$ & $\begin{array}{l}\text { Sig. }(2- \\
\text { Tailed })\end{array}$ & $\eta^{2}$ \\
\hline \multirow{3}{*}{ USE } & \multirow{3}{*}{$\begin{array}{l}\text { Item } 1 \text { ( } 18 \mathrm{Us} \text { ): Using the Internet } \\
\text { helps me solve problems that I } \\
\text { would not be able to solve through } \\
\text { other means }\end{array}$} & SP* & 2.87 & 0.587 & 545.15 & & \\
\hline & & $\mathrm{AM} * *$ & 2.65 & 0.743 & 463.75 & & \\
\hline & & Total & 2.71 & 0.712 & & .000 & .020 \\
\hline \multirow{9}{*}{ LEARNING } & \multirow{3}{*}{$\begin{array}{l}\text { Item } 2 \text { ( } 17 \mathrm{Ls}) \text { : I use Google Drive } \\
\text { to work with my classmates }\end{array}$} & SP* & 2.68 & 1.007 & 534.15 & & \\
\hline & & $\mathrm{AM}^{* *}$ & 2.43 & 0.987 & 467.63 & & \\
\hline & & Total & 2.49 & 0.998 & & .001 & .012 \\
\hline & \multirow{3}{*}{$\begin{array}{l}\text { Item } 3 \text { (19Ls): The social } \\
\text { networks help me with my studies }\end{array}$} & SP* & 2.32 & 0.763 & 398.87 & & \\
\hline & & $\mathrm{AM} * *$ & 2.68 & 0.834 & 515.43 & & \\
\hline & & Total & 2.58 & 0.831 & & .000 & .038 \\
\hline & \multirow{3}{*}{$\begin{array}{l}\text { Item } 4(20 \mathrm{Ls}): \text { I learn more on } \\
\text { the Internet than in class }\end{array}$} & SP* & 2.02 & 0.702 & 432.86 & & \\
\hline & & $\mathrm{AM} * *$ & 2.25 & 0.807 & 503.42 & & \\
\hline & & Total & 2.19 & 0.787 & & .000 & .015 \\
\hline \multirow{10}{*}{$\begin{array}{l}\text { C R I T I C A L } \\
\text { THINKING }\end{array}$} & \multirow{3}{*}{$\begin{array}{l}\text { Item } 5 \text { (16Cs): Knowing the } \\
\text { Internet works in depth will help } \\
\text { me find work in the future }\end{array}$} & SP* & 3.13 & 0.641 & 537.25 & & \\
\hline & & $\mathrm{AM} * *$ & 2.91 & 0.781 & 466.54 & & \\
\hline & & Total & 2.97 & 0.753 & & .000 & .015 \\
\hline & \multirow{3}{*}{$\begin{array}{l}\text { Item } 6 \text { ( } 17 \mathrm{Cs}): \text { I use the Networks } \\
\text { to help people who have problems }\end{array}$} & SP* & 2.16 & 0.728 & 418.77 & & \\
\hline & & $\mathrm{AM} * *$ & 2.43 & 0.817 & 508.4 & & \\
\hline & & Total & 2.36 & 0.804 & & .000 & .023 \\
\hline & \multirow{3}{*}{$\begin{array}{l}\text { Item } 7 \text { (18Cs): I try to behave } \\
\text { correctly and respectfully in the } \\
\text { Networks }\end{array}$} & SP* & 3.65 & 0.568 & 567.07 & & \\
\hline & & $\mathrm{AM}^{* *}$ & 3.35 & 0.722 & 456 & & \\
\hline & & Total & 3.43 & 0.708 & & .000 & .038 \\
\hline & Item 8 (19Cs): I use the same & SP* & 3.59 & 0.574 & 537.56 & & \\
\hline
\end{tabular}




\begin{tabular}{|l|l|l|l|l|l|l|l|}
\hline \multirow{2}{*}{$\begin{array}{l}\text { values of respect on the Internet } \\
\text { as I do in real life }\end{array}$} & AM** & 3.37 & 0.742 & 466.43 & & \\
\cline { 2 - 7 } & Total & 3.02 & 0.874 & & .000 & .016 \\
\hline $\begin{array}{llllll}\text { Item 9 (20Cs): I monitor } \\
\text { everything there is on the Internet }\end{array}$ & SP* & 2.77 & 0.940 & 415.34 & & \\
\cline { 2 - 8 } \\
$\begin{array}{l}\text { about me to have a good } \\
\text { reputation online }\end{array}$ & AM** & 3.11 & 0.832 & 509.61 & & \\
\cline { 2 - 8 } & Total & 2.73 & 0.846 & & .000 & .025 \\
\hline
\end{tabular}

* (SP) Spanish sample $\mathrm{N}=253 * *$ (AM) Latin American sample (Colombia, Ecuador and Mexico) $\mathrm{N}=716$ Note. $\mathrm{p}<.05$

Table 6. Digital Content Creation. Source: Own elaboration

The greatest significant differences between both contexts are reflected in the area of "Critical thinking", where significant differences are found in all items with medium effects in the $\eta^{2}$ value where the effect size is maintained between 0.04 and 0.11 . In the item "I try to have an adequate and respectful behavior in the networks", an important difference is observed in the behavior of the students, which highlights $13 \%$ in the case of Latin America and 3\% in the case of Spain, who rarely or never behave in networks or is respectful $(M 1=3.65 \mathrm{SD}=0.56 \mathrm{M} 2=3.35 \mathrm{SD}=0.72$ $\left.\mathrm{U}=69809.50 \mathrm{P}<0.000 \eta^{2}=0.038\right)$. On the other hand, the digital reality seems to be placed more on the preoccupation of Latin American students analyzed $(M=3.11 \mathrm{SD}=0.83)$ that in the Spanish ones $(M=2.77 S D=0.94)$ with a statistically significant difference $\left(U=72950.00 \eta^{2}=0.025\right)$.

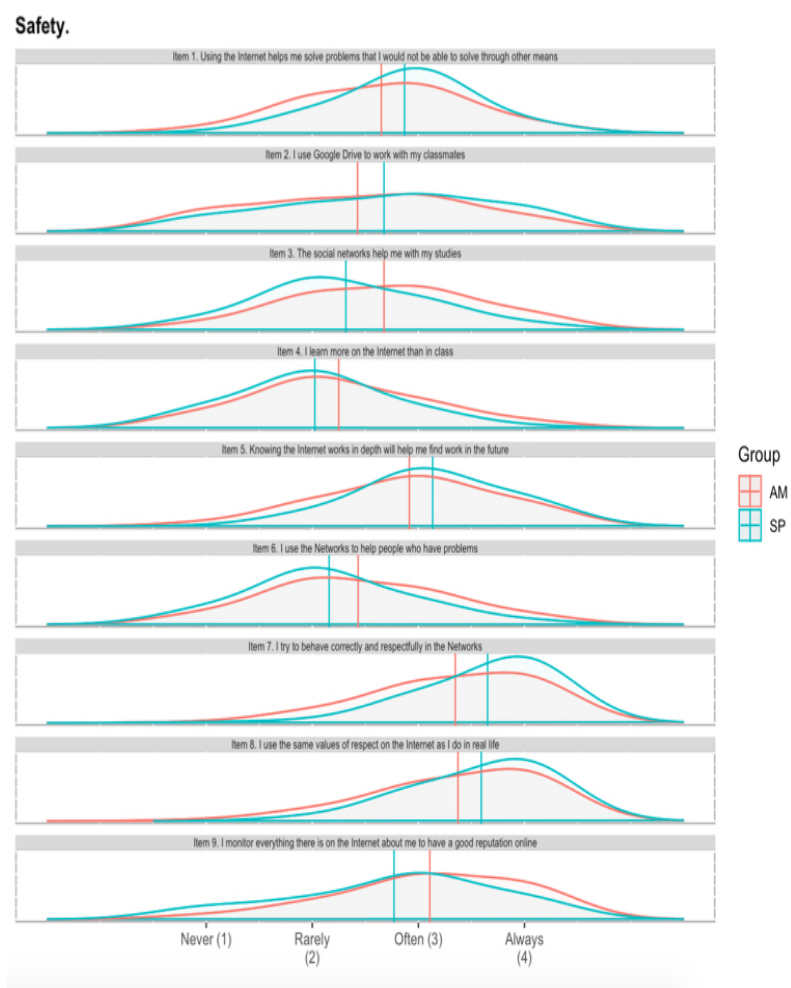

Figure 9. Distribution figures of the items with statistically significant differences and noticeable effect size in the area of safety.Source: Own elaboration 


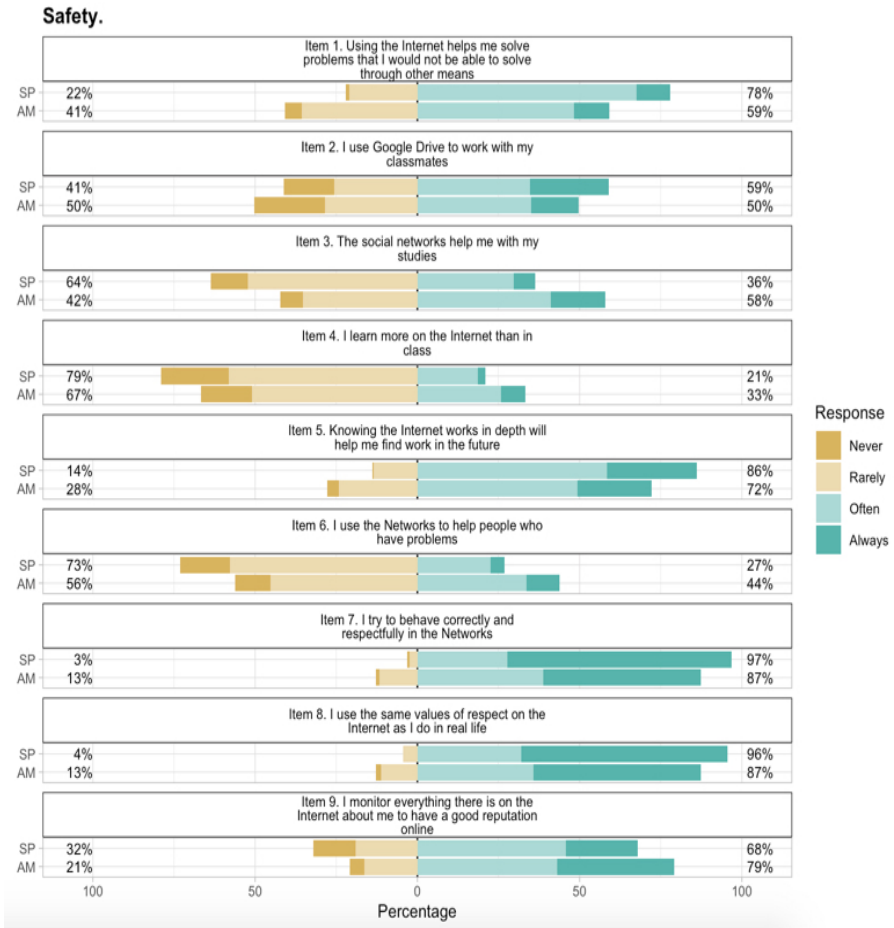

Figure 10. Graphical representation of the response percentages according to items with statistically significant differences and noticeable effect size in the area of safety. Source: Own elaboration

Significant differences in the area of "Learning" are shown in Figures 9 and 10. The Latin American students seem to learn more from the internet that the Spanish ones, despite neither of the two samples declare to learn more from the Internet than in the classroom (M1=2.05 SD $=0.70$ $M 2=2.25 \mathrm{SD}=0.80 \mathrm{U}=77383.50 \mathrm{P}<0.000 \eta^{2}=0.015$ ). If seems evident that in Latin America, the social networks help the students more in their learning process than in the case of the Spanish sample ( $M 1=2.32 \mathrm{SD}=0.76 \mathrm{M} 2=2.68 \mathrm{SD}=0.83 \mathrm{U}=68784.00 \mathrm{P}<0.000 \eta^{2}=0.038$ ), where a third part of the students very often or always learn from the social networks.

\section{e. Problem solving}

The last sub-area analyzed is the area where both samples showed fewer significant differences. As shown on Table 7, only two items had a different behavior.

\begin{tabular}{|c|c|c|c|c|c|c|c|}
\hline $\begin{array}{l}\text { Areas of } \\
\text { study }\end{array}$ & $\begin{array}{l}\text { Items presenting significant } \\
\text { differences }\end{array}$ & & Mean & SD & $\begin{array}{l}\text { Mean } \\
\text { Rank }\end{array}$ & $\begin{array}{c}\text { Sig. } \\
(2- \\
\text { Tailed) }\end{array}$ & $\eta^{2}$ \\
\hline \multirow{6}{*}{ LEARNING } & \multirow{3}{*}{$\begin{array}{l}\text { Item } 1 \text { ( } 22 \mathrm{Lp}) \text { : I record videos and } \\
\text { edit them for class work }\end{array}$} & SP* & 2,06 & 0,770 & 417,13 & & \\
\hline & & $\mathrm{AM} * *$ & 2,36 & 0,898 & 508,98 & & \\
\hline & & Total & 2,28 & 0,876 & & .000 & .023 \\
\hline & \multirow{3}{*}{$\begin{array}{l}\text { Item } 2(23 \mathrm{Lp}): \text { I share my own } \\
\text { contents on the Internet so that } \\
\text { others can learn }\end{array}$} & SP* & 1,68 & 0,704 & 431,61 & & \\
\hline & & $\mathrm{AM} * *$ & 1,96 & 0,920 & 503,87 & & \\
\hline & & Total & 1,88 & 0,877 & & .000 & .015 \\
\hline
\end{tabular}

* (SP) Spanish sample $\mathrm{N}=253 * *$ (AM) Latin American sample (Colombia, Ecuador and Mexico) $\mathrm{N}=716$ Note. $\mathrm{p}<.05$.

Table 7. Digital Content Creation. Source: Own elaboration 


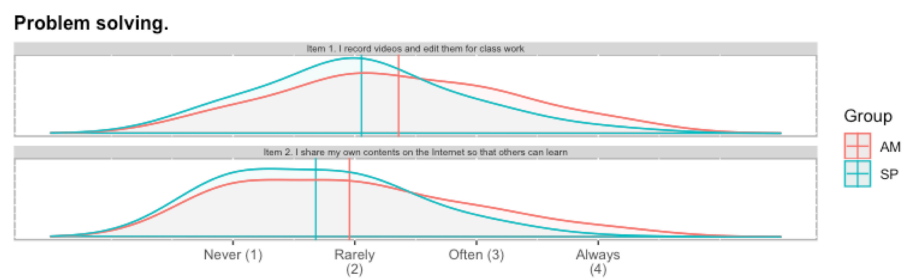

Figure 11. Distribution figures of the items with statistically significant differences and noticeable effect size in the area of problem solving. Source: Own elaboration

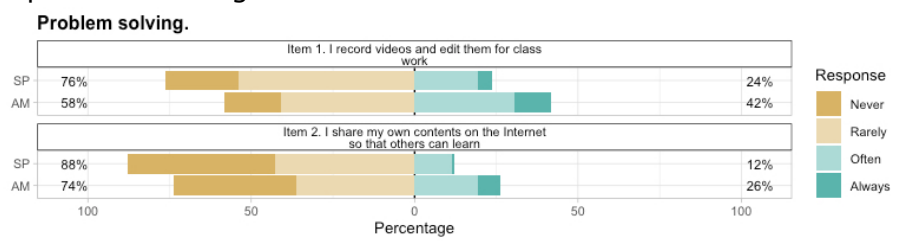

Figure 12. Graphical representation of the response percentages according to items with statistically significant differences and noticeable effect size in the area of problem solving. Source: Own elaboration

In the case of item "Creatively using digital tools for recording and editing videos for work in the classroom" ( $\mathrm{M} 1=2.06 \mathrm{SD}=0.77 \mathrm{M} 2=2.36 \mathrm{SD}=0.89 \mathrm{U}=73404.00 \mathrm{P}<0.000 \eta^{2}=0.023$ ) as well as "Sharing self-created content on the Internet so that others learn" (M1=1.68 SD=0.70 M2=1.96 $\left.\mathrm{SD}=0.92 \mathrm{U}=77066.00 \mathrm{P}<0.000 \eta^{2}=0.015\right)$, the Latin American students had a more proactive attitude, with $42 \%$, as compared to $24 \%$ in case of the Spanish students, almost double for the first item, and more than double for the second item, with $26 \%$ of the Latin American students as compared to $12 \%$ of the Spanish ones.

\section{Discussion and conclusions}

The development of smart learning has reached during pandemic situation a milestone with all students using smart devices for learning in informal environments, becoming a growing trend in education and highlighting its relevance as pointed in previous studies (Dneprovskaya, Komleva, \& Urintsov 2020; Wang \& Nunes 2019; Zhu, Sun, \& Riezebos 2016). Moreover, digital competences, that have been, since their endorsement, and essential training issue, studied from different perspectives: creative and informal (Taddeo \& Tirocci 2019; Masanet, Guerrero-Pico, \& Establés 2019), in the initial training of preservice teachers (Girón-Escudero, Cózar-Gutiérrez, \& GonzálezCalero 2019; Güneş \& Bahçivan 2018; Silva, Usart, \& Lázaro-Cantabrana 2019) and in the training of university teachers (Blau and Shamir-Inbal 2017; Instefjord \& Munthe, 2016) are remarked as an inherent element to the training needed in the society of information. This article offers a new approach, considering the intensive exposure of population to digital devices during pandemic situation, specifically during global lockdown. In this regard, to the traditional study of digital competences in the five areas (Redecker \& Punnie, 2017) this research adds contextual areas of study regarding Use, Learning and Critical Thinking. It supposes a new and deeper perspective to the traditional focused on learning contexts (Blau \& Shamir-Inbal, 2017).

As made evident in previous studies in the academic environment of the digital competencies and their development (Iordache, Mariën, and Baelden 2017; From 2017; Feijoo-Fernández, Sádaba, \& Bugueño, 2020) or international reports (ITU 2018), their evaluation or measurement is a complex task that requires technical mechanisms that are continuously updated. However, the 
measurement of these new competencies, liked to the recognition of new learning spaces mediated by connected smart devices (Che, Cheng, and Chew 2016; Zhu, Yu, and Riezebos 2016) offer a more adequate view, alongside rationale that are closer to the current real-world use of technology by the younger population. The comparative view of the work conducted allows for a two-sided lecture: the first, based on the fact that, as highlighted in the indicators of digital economy set out by the OCDE (2018) and in line with those of the ITU (2018), the digital skills are the cornerstone for a society's progress, based on the training and skills of the population, and in second place, that the digital competencies are a guarantee of an efficient universal access towards a changing education that promotes new competencies but demands new necessities.

The work presented is found in line with the last report by the OECD (2020) that constitutes part of the OECD Learning Framework 2030, because, although the analysis of the data has been focused on the analysis of significant differences between the samples, the great quantity of even results should be noted, despite the analysis being conducted on samples from different countries. In agreement with tenets of Smart Learning, focused on the learning of the student, obtaining maximum performance of the formative, formal and informal itineraries (Zhu, Yu, and Riezebos 2016), it can be concluded, with the results obtained, that the main differences between the countries are precisely centered in the two areas: "Learning", where a total of 13 items with significant differences were found; and "Critical Thinking" with 10 items presenting differences. "Use" seemed to be the area with fewer significant differences only 6 items from the 75 studied.

Having in mind the limitations of the work presented, it can be stated that it is a novel contribution that makes evident not only that the study of the digital competencies remain an important issue to be developed and studied in higher education but the necessity to amplify it in a contextual framework, regarding not only "Learning" but "Use" and "Critical thinking". It is therefore confirmed that the use of technology has been globalized, however, their efficient use for learning has yet to be treated in depth in education policies and national actions that can guarantee the real exploitation of technology for the training of participatory, democratic citizens with ecological values, and which is related, without a doubt, with the training not only of the students, but of the professors who are currently actively teaching.

\section{Acknowledgments}

This work is conducted with the support of the "Youtubers and Instagrammers: Media competence in emerging prosumers" Project (RTI2018-093303-B-I00).

\section{References}

Bakken, J. P., Uskov, V. L., \& Penumatsa, A. (2019). Smart Education and e-Learning 2018. Springer. https:// doi.org/10.1007/978-3-319-92363-5

Blau, I., \& Shamir-Inbal, T. (2017). Digital competences and long-term ICT integration in school culture: The perspective of elementary school leaders. Education and Information Technologies, 22(3), 769-787. https://doi.org/10.1007/s10639-015-9456-7

Buckingham, D. (2020). Epilogue: Rethinking digital literacy: Media education in the age of digital capitalism. Digital Education Review, 37. https://doi.org/10.1344/der.2020.37.230-239

Cabero, J., Romero, R., \& Palacios, A. (2020). Evaluation of Teacher Digital Competence Frameworks Through Expert Judgement: the Use of the Expert Competence Coefficient. Journal of New Approaches in Educational Research, 9(2), 275-293. doi: 10.7821/naer.2020.7.578

Carretero, S., Vuorikari, R., \& Punie, Y. (2017). DigComp 2.1: The Digital Competence Framework for Citizens with eight proficiency levels and examples of use. Publications Office of the European Union. Luxemburg. https://doi.org/10.2760/38842 
Crawford, J., Butler-Henderson, K., Rudolph, J., Malkawi, B., Glowatz, M., Burton, R., Magni, P.A. \& Lam, S. (2020). COVID-19: 20 countries' higher education intra-period digital pedagogy responses. Int. Perspect. Interact. Educ., 3, 1-20, doi:10.37074/jalt.2020.3.1.7.

Chen, N. S., Cheng, I. L., \& Chew, S. W. (2016). Evolution is not enough: Revolutionizing current learning environments to smart learning environments. International Journal of Artificial Intelligence in Education, 26(2), 561-581.

Cohen, J. (1988). Statistical power analysis for the behavioral sciences, 2nd edition. New York: Erlbaum.

Di Pietro, G., Biagi, F., Costa, P., Karpiński Z., \& Mazza, J. (2020). The likely impact of COVID-19 on education: Reflections based on the existing literature and recent international datasets. European Union.

Dneprovskaya, N., Komleva, N. \& Urintsov, A. (2020). The Knowledge Management Approach to Digitalization of Smart Education. In Z. Hu, Petoukhov, S. \& M. He (Ed.). Advances in Intelligent Systems for Medicine and Education II, pp. 641-650. https://doi.org/10.1007/978-3-030-12082-5_58

Feijoo-Fernández, B., Sádaba, C., \& Bugueño, S. (2020). ¿Nivel experto o ingenuo? Detección y confianza de los niños en la publicidad que reciben a través de sus dispositivos móviles. Perfiles de usuario. ZER: Revista de Estudios de Comunicación, 25(48), 227-244. https://www.ehu.eus/ojs/index.php/Zer/ article/view/21520

From, J. (2017). Pedagogical Digital Competence-Between Values, Knowledge and Skills. Higher Education Studies, 7(2), 43. https://doi.org/10.5539/hes.v7n2p43

García-Ruiz, R. \& Pérez-Escoda, A. (2019). Empoderar a la ciudadanía mediante la educación en medios. [Empower citizenship through education in digital media]. Hamutáy. Revista de divulgación científica de la Universidad Alas Peruanas, 6(2), 7-23. http://dx.doi.org/10.21503/hamu.v6i2.1771

García-Ruiz, R. \& Pérez-Escoda, A. (2021). La competencia digital como clave para fortalecer el uso responsable de internet. Campus Virtuales, 10, 59-71. http://www.uajournals.com/ojs/index.php/campusvirtuales/ article/view/781

Gardner, D. \& Davis. K. (2014). App Generation. How today's Youth Navigate Identity, Intimacy and Imagination in a Digital World. Yale University Press.

Girón Escudero, V., Cózar Gutiérrez, R., \& González-Calero Somoza, J. A. (2019). Análisis de la autopercepción sobre el nivel de competencia digital docente en la formación inicial de maestros/as. Revista Electrónica Interuniversitaria De Formación Del Profesorado, 22(3), 193-218. https://doi.org/10.6018/ reifop. 373421

Ihlebæk, K. A. (2018). Participatory Culture in a Networked Era. Information, Communication \& Society. https://doi.org/10.1080/1369118x.2017.1417462

Iordache, C., Mariën, I., \& Baelden, D. (2017). Developing Digital Skills and Competences: A Quick-Scan Analysis of 13 Digital Literacy Models. Italian Journal of Sociology of Education, 9(1), 6-30. https:// doi.org/10.14658/pupj-ijse-2017-1-2

ITU (2018). Measuring the information Society Report 2018. Volume 1. Geneva: ITU. https://www.itu.int/en/ ITU-D/Statistics/Documents/publications/misr2018/MISR-2018-Vol-1-E.pdf

Hwang, G. J. (2014). Definition, framework and research issues of smart learning environments-a contextaware ubiquitous learning perspective. Smart Learning Environments, 1. https://doi.org/10.1186/ s40561-014-0004-5

Hwang, G. J. \& Choi, H.J. (2016). Influence of smart devices on the cognition and interest of underprivileged students in smart education. Indian Journal of Science and Technology, 9(44), 1-4. https://doi.org/ $10.17485 /$ ijst/2016/v9i44/105171

Li, K. C., Tsang, E. Y. M., \& Wong, B. T. M. (Eds.). (2020). Innovating Education in Technology-Supported Environments. Springer Singapore.

Marinoni, G., Land, H. \& Jensen, T. (2020). The Impact of Covid-19 on Higher Education around the World; IAU Global Survey Report; UNESCO: Paris, France; International Association of Universities: Paris, France. 
Masanet, M.J., Guerrero-Pico, M. \& Establés, M.J. (2019) From digital native to digital apprentice. A case study of the transmedia skills and informal learning strategies of adolescents in Spain. Learning, Media and Technology, 44:4, 400-413, DOI: 10.1080/17439884.2019.1641513

Nachar, N. (2008). The Mann-Whitney U: A test for assessing whether two independent samples come from the same distribution. Tutorials in Quantitative Methods for Psychology, 4(1), 13-20.

Newman, N., Fletcher, R., Schulz, A., Andi, s., Robertson, C., \& Kleis, R. (2021). Reuters Institute Digital News Report 2021. Reuters Institute. https://reutersinstitute.politics.ox.ac.uk/sites/default/files/2021-06/ Digital_News_Report_2021_FINAL.pdf

OECD. (2020). Schooling Disrupted, Schooling Rethought. How the COVID-19 Pandemic Is Changing Education. OECD. Retrieved from: https://read.oecd-ilibrary.org/view/? ref=133_133390-1rtukncOhi\&title=Schooling-disrupted-schooling-rethought-How-the-Covid-19pandemic-is-changing-education

Pedrero-Esteban, L.M. \& Pérez-Escoda, A. (2021). Democracy and digitisation: Ethical Implications of AI in the Personalisation of Content through Voice Interfaces. RECERCA. Revista de Pensament $i$ Anàlisi, 26(2), 1-24. https://doi.org/10.6035/recerca.4666

Pettersson, F. (2018). On the issues of digital competence in educational contexts - a review of literature. Education and Information Technologies, 23(3), 1005-1021. https://doi.org/10.1007/ s10639-017-9649-3

Pérez-Escoda, A., García-Ruiz, R., and Lena-Acebo, F. (2021). Brecha digital de género en Iberoamérica. Análisis en estudiantes universitarios. Aula Abierta, 50(1), 505-514. https://doi.org/10.17811/ rifie.50.1.2021.505-514

Pérez-Escoda, A., Pedrero-Esteban, L.M., Rubio, J. y Jiménez, C. (2021). Fake news reaching young people in social networks: Distrust challenging media literacy. Publications, 9(2), 24. https://doi.org/10.3390/ publications 9020024

Pérez-Escoda, A., \& Pedrero Esteban, L. M. (2021). Retos del periodismo frente a las redes sociales, las fake news y la desconfianza de la generación Z. Revista Latina De Comunicación Social, (79), 67-85. https://doi.org/10.4185/RLCS-2021-1519

Redecker, C. \& Punie, Y. (2017). European Framework for the Digital Competence of Educators. Luxembourg: European Union.

Taddeo, G. \& Tirocchi, S. (2019). Transmedia teens: the creative transmedia skills of Italian students, Information, Communication \& Society, DOI: 10.1080/1369118X.2019.1645193

Tapscott, D. (2008). Grow up digital. How the Net Generation is changing your world. McGraw Hill Education.

Tripathi, G., \& Ahad, M. A. (2019). IoT in Education: An Integration of Educator Community to Promote Holistic Teaching and Learning. In 1st International Conference on Soft Computing in Data Analytics (SCDA) (pp. 675-683). Springer International Publishing AG. https://doi.org/10.1007/978-981-13-0514-6_64

Van Deursen, A.J. (2020). Digital Inequality During a Pandemic: Quantitative Study of Differences in COVID-19-Related Internet Uses and Outcomes Among the General Population. Journal of Medical Internet Research, 22(8) e20073. https://doi.org/10.2196/20073

Wang, M., \& Nunes, M. B. (2019). Matching serious games with museum's educational roles: smart education in practice. Interactive Technology and Smart Education, 16(4) 319-342. https://doi.org/10.1108/ ITSE-03-2019-0013

Zhu, Z.-T., Yu, M.-H., \& Riezebos, P. (2016). A research framework of smart education. Smart Learning Environments, 3(1), 4. https://doi.org/10.1186/s40561-016-0026-2 